\title{
Flagellation of Salmonella typhimurium Treated with Nalidixic Acid
}

\author{
By TETSUO IINO*, TOMOKO OGUCHI AND KAZUHIRO KUTSUKAKE \\ Laboratory of Genetics, Department of Biology, Faculty of Science, University of Tokyo, Hongo, \\ Tokyo 113, Japan
}

(Received 24 June 1986; revised 21 October 1986)

Filamentous cells of Salmonella typhimurium, obtained after treatment with nalidixic acid in the exponential phase of growth, elongated up to $10 \mu \mathrm{m}$, corresponding to 4 unit cell lengths, per nucleoid. During elongation, division of nucleoids and septum formation did not occur, but de novo formation of flagella continued. Most of the filamentous cells were motile, and flagella were evenly distributed on their surface.

\section{INTRODUCTION}

During the exponential growth phase, flagella, in a peritrichously flagellated bacterium, double in a cell cycle and distribute approximately evenly to the two daughter cells. Consequently, the average number of flagella per bacterium is maintained constant (Iino, 1974). Increase of number of flagella is coupled to a certain process in the cell cycle, which proceeds by cooperation of various events, such as cell elongation, DNA replication, division of nucleoids and cell fission. Examination of the correlation between flagellation and these events may provide valuable information for elucidation of the regulatory system which couples flagellation with the cell cycle. The effect of nalidixic acid (NAL) on flagellation of Salmonella typhimurium was examined in this work. This antibiotic inhibits primarily DNA replication, interacting with the A-component of DNA gyrase, and affects various events of the cell cycle (Goss et al., 1964, 1965; Sugino et al., 1977; Westmacott \& Primrose, 1977; Higgins et al., 1978; Edwards \& McCann, 1983).

\section{METHODS}

Organism and growth. A peritrichously flagellated strain of $S$. typhimurium, TM2, was used. Characteristics of flagellation of this strain were described by Iino (1974). Difco nutrient broth (NB) was used as liquid medium. Nutrient agar (NA) was prepared by the addition of $1.2 \%(\mathrm{w} / \mathrm{v})$ agar to NB.

To examine the effect of NAL, a stock solution (100 mg NAL in $1 \mathrm{ml} 1 \mathrm{M} \mathrm{NaOH}$ ) was added to $20 \mathrm{ml} \mathrm{NB}$ in a $100 \mathrm{ml}$ Erlenmeyer flask to give the desired final NAL concentration. The medium was inoculated with exponentially growing cells at a final concentration of $10^{7}$ cells $\mathrm{ml}^{-1}$ and incubated at $37^{\circ} \mathrm{C}$ with gentle shaking. Cell numbers were counted with a bacterial counting chamber (Elma, Tokyo) after fixation with formaldehyde $(5 \%, v / v)$. Viability was estimated from colony counts on NA.

Observation of cell shape and cellular motility. Cells were examined in an Olympus VANOX AHB-LB microscope with positive phase-contrast optics at a magnification of $400 \times$. Cell shapes were arbitrarily classified as filament, rod or spindle. The length of each cell was measured with an ocular micrometer and cells longer than $5 \mu \mathrm{m}$ were classified as filamentous cells. As it was difficult to count motile cells directly, the motile cell fraction was estimated by subtracting the number of non-motile cells from total cell number, which was estimated from the formaldehyde fixed sample.

Observation of flagellation. Cells fixed with formaldehyde were washed with distilled water by centrifugation, suspended in distilled water, smeared on a glass slide, and stained with the Shionogi flagellar staining reagent (Shionogi, Osaka) (Iino \& Enomoto, 1971). From each stained sample, 100 to 150 cells were photographed with an

Abbreviations: NAL, nalidixic acid; u.c.l., unit cell length. 
Olympus PM-10-A camera. The number of flagella per cell and cell length were measured on the photographs at a final magnification of $1500 \times$.

Observation of nucleoids. After centrifugation, cells were treated with $50 \mu \mathrm{g}$ ethidium bromide $\mathrm{ml}^{-1}$ (Kuroiwa et al., 1981). Approximately 100 cells from each sample were photographed with an Olympus AH-RFL-LB incident fluorescence microscope equipped with phase optics. The number of nucleoids per cell and cell length were measured on the photographs.

\section{RESULTS AND DISCUSSION}

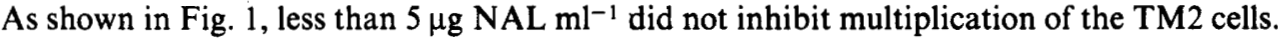
After treatment with 10 to $50 \mu \mathrm{g} \mathrm{NAL} \mathrm{ml}{ }^{-1}$ for $20 \mathrm{~h}$, cell multiplication was inhibited and viability decreased. Survival curves after treatment with $10 \mu \mathrm{g} \mathrm{NAL} \mathrm{ml}{ }^{-1}$ indicated that the effect observed after $20 \mathrm{~h}$ treatment was already attained after $2 \mathrm{~h}$ (data not shown).

In the range 10 to $25 \mu \mathrm{g} \mathrm{NAL} \mathrm{ml}{ }^{-1}$, in which cell multiplication was inhibited, formation of filamentous cells without septa was enhanced while the proportion of rod-shaped cells decreased (Fig. 2), as observed in Escherichia coli (Goss et al., 1964). With higher NAL concentrations, the proportion of filamentous cells decreased again at the expense of both rod-shaped and spindleshaped cells. This result conforms with previous reports that the treatment of rod-shaped bacteria with NAL caused inhibition of septum formation resulting in the production of filamentous cells (Goss et al., 1964; Westmacott \& Primrose, 1977; Edwards \& McCann, 1983).

Cultures treated with $10,25,50,75$ and $100 \mu \mathrm{g} \mathrm{NAL} \mathrm{ml}^{-1}$ were examined for motility (Table 1). The motile cell fraction at the beginning of the NAL treatment was $94 \%$. After treatment for $20 \mathrm{~h}$, approximately 75 to $85 \%$ of the filamentous cells were motile at all NAL concentrations. Motility of the rod-shaped cells was inhibited at those concentrations higher than $75 \mu \mathrm{g} \mathrm{NAL}$ $\mathrm{ml}^{-1}$ (Table 1). Only rarely were motile spindled-shaped cells detected. The motile cell fraction of each sample (40 to 80\%) was much larger than the viable fraction $(0.1 \%)$ (cf. Table 1 and Fig. 1). This indicates that the cells which could not multiply after the NAL treatment were still motile.

Cell length and number of flagella were simultaneously measured on samples treated for $2 \mathrm{~h}$ with $10 \mu \mathrm{g} \mathrm{NAL} \mathrm{mil}{ }^{-1}$, the minimum concentration which inhibited cell multiplication. At the start of the treatment, the average cell length was $3.8 \mu \mathrm{m}$, the majority $(85 \%)$ of the cells being in the range of $2.5 \mu \mathrm{m}$ to $5.0 \mu \mathrm{m}$. In a typical cell cycle, therefore, a cell elongates up to $5.0 \mu \mathrm{m}$ and divides producing two daughter cells $2.5 \mu \mathrm{m}$ in length. Hereafter $2.5 \mu \mathrm{m}$ was taken as one unit cell length (u.c.l.).

After the NAL treatment, distribution of cell length became broad and the maximum length approached $20 \mu \mathrm{m}$, corresponding to 8 u.c.l. Cells were grouped according to their u.c.l. values and mean number of flagella was calculated for the cells of each group (Fig. 3). With increasing cell length, the number of flagella per cell increased up to 6 u.c.l. Flagella were evenly distributed over the cell surface. These results mean that, during elongation of NAL treated cells, de novo formation of flagella continues.

At the start of the NAL treatment, cells contained either one or two nucleoids and the average increased from one to two with growth of the cell (Fig. $4 a$ ). In the filamentous cells, produced by treatment with $10 \mu \mathrm{g} \mathrm{NAL} \mathrm{ml}{ }^{-1}$ for $2 \mathrm{~h}$, the mean number of nucleoids stayed between one and two and the overall mean, 1.4, was the same as that of the untreated cells (Fig. $4 b$ ). This indicates that no significant multiplication of nucleoids occurred during the NAL treatment, and that the cell length per nucleoid increased in the filamentous cells.

Goss et al. (1964) reported of NAL treated $E$. coli cells that the resulting filamentous cells, although motile, were non-viable when diluted and plated on agar media. This was also the case with $S$. typhimurium in the present study, suggesting that NAL has no significant inhibitory effect on bacterial motility.

The observations of Goss et al. (1964) did not discriminate whether or not de novo formation of flagella occurred in the presence of NAL, because the motility they observed might have been attributable to the preexisting flagella. The present study shows that the bacteria can produce flagella de nove during growth in the presence of NAL, as the number of flagella in filamentous cells increased almost linearly with the increase of cell length (Fig. 3). 


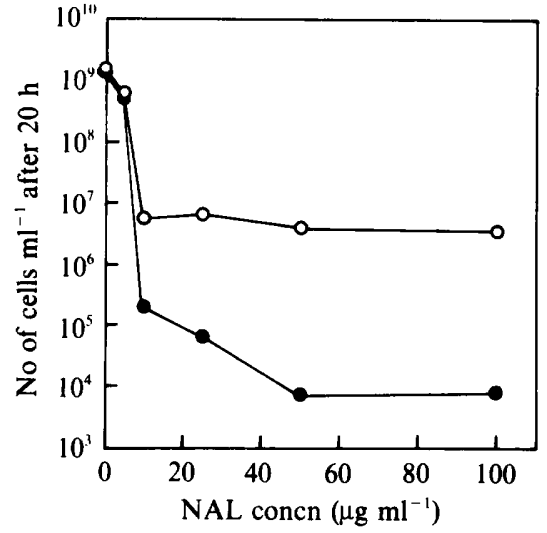

Fig. 1

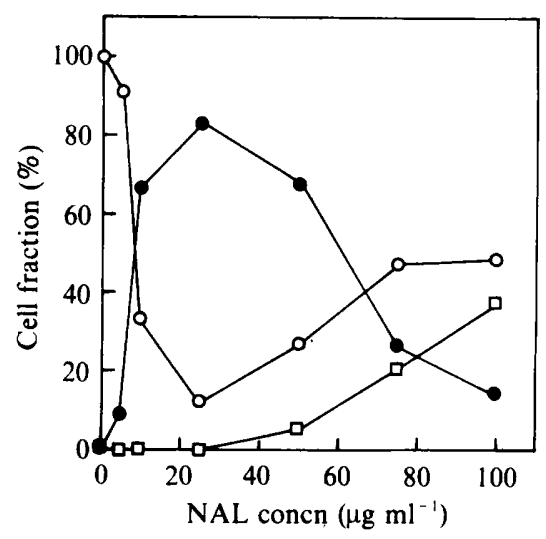

Fig. 2

Fig. 1. Total cell numbers $(O)$ and survival (O) of $S$. typhimurium TM2 treated with various concentrations of NAL for $20 \mathrm{~h}$ at $37^{\circ} \mathrm{C}$ in NB. Cell number at $0 \mathrm{~h}$ was $1 \times 10^{7} \mathrm{ml}^{-1}$.

Fig. 2. Fractions of filamentous (O), rod-shaped $(O)$ and spindle-shaped $(\square)$ cells in cultures of $S$. typhimurium TM2 treated with various concentrations of NAL for $20 \mathrm{~h}$ at $37^{\circ} \mathrm{C}$ in NB.

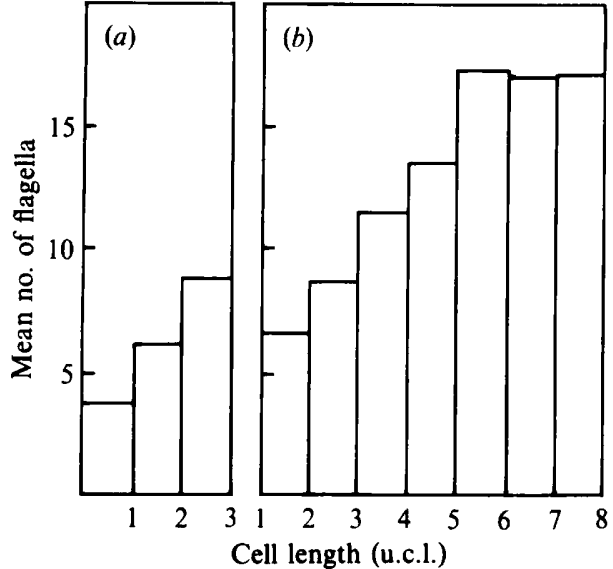

Fig. 3

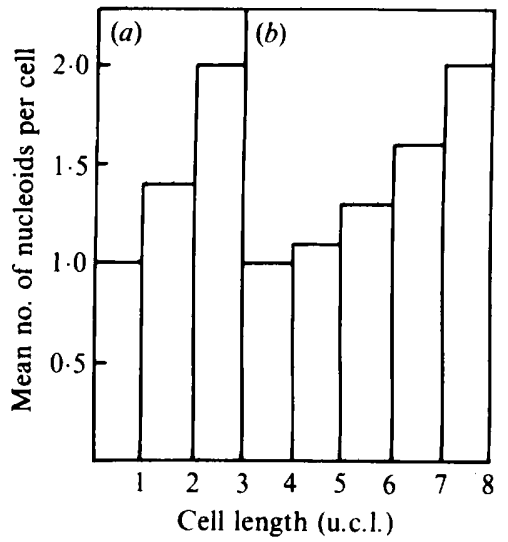

Fig. 4

Fig. 3. Distribution of mean number of flagella per cell among the cells of different length fractions in a culture of $S$. typhimurium TM2, at $0 \mathrm{~h}(a)$, and after treatment with $10 \mu \mathrm{g} \mathrm{NAL} \mathrm{ml} l^{-1}$ for $2 \mathrm{~h}$ at $37^{\circ} \mathrm{C}$ in NB (b). One u.c.l. corresponds to $2.5 \mu \mathrm{m}$.

Fig. 4. Distribution of mean number of nucleoids per cell among the cells of different length fractions in a culture of $S$. typhimurium TM2, at $0 \mathrm{~h}(a)$, and among the filamentous cells after treatment with $10 \mu \mathrm{g} \mathrm{NAL} \mathrm{ml} l^{-1}$ for $2 \mathrm{~h}$ at $37^{\circ} \mathrm{C}$ in NB (b). One u.c.l. corresponds to $2.5 \mu \mathrm{m}$.

Table 1. Frequency of motile cells in populations of different cell shape after $20 \mathrm{~h}$ NAL treatment The results are means \pm SD of triplicate samples.

$\begin{array}{cccc}\begin{array}{c}\text { NAL } \\ \text { concn } \\ \left(\mu \mathrm{g} \mathrm{ml}^{-1}\right)\end{array} & \begin{array}{c}\text { Total } \\ \text { cells }\end{array} & \begin{array}{c}\text { Rod-shaped } \\ \text { cells }\end{array} & \begin{array}{c}\text { Frequency of motile cells }(\%) \\ \text { in the population of : } \\ \text { cells }\end{array} \\ 10 & 82 \pm 4 & 67 \pm 8 & 87 \pm 4 \\ 25 & 82 \pm 3 & 63 \pm 9 & 89 \pm 3 \\ 50 & 72 \pm 7 & 68 \pm 11 & 81 \pm 8 \\ 75 & 45 \pm 8 & 16 \pm 9 & 75 \pm 10 \\ 100 & 36 \pm 6 & 4 \pm 3 & 82 \pm 8\end{array}$


This work was supported by grants in aid for scientific research from the Ministry of Education, Science and Culture in Japan.

\section{REFERENCES}

EDWARDS, C. \& MCCANN, R. J. (1983). The effects of nalidixic acid on respiratory activity of asynchronous and synchronous cultures of Alcaligenes eutrophus. Journal of General Microbiology 129, 1-5.

Goss, W. A., DeITZ, W. H. \& Cook, T. M. (1964). Mechanism of action of nalidixic acid on Escherichia coli. Journal of Bacteriology 88, 1112-1118.

Goss, W. A., Deitz, W. H. \& CoOK, T. M. (1965). Mechanism of action of nalidixic acid on Escherichia coli. II. Inhibition of deoxyribonucleic acid synthesis. Journal of Bacteriology 89, 1068-1074.

Higgins, N. P., Peebles, C. L., Sugino, A. \& Cozzarelli, N. R. (1978). Purification of subunits of Escherichia coli DNA gyrase and reconstitution of enzymatic activity. Proceedings of the National Academy of Sciences of the United States of America 75, 1773-1777.

IINO, T. (1974). Assembly of Salmonella flagellin in vitro and in vivo. Journal of Supramolecular Structure 2, $372-384$.
Inno, T. \& Enomoto, M. (1971). Motility. Methods in Microbiology 5A, 145-163.

Kuroiwa, T., Nishibayashi, S., Kawano, S. \& SUZUKI, T. (1981). Visualization of DNA in various phages (T4, $\chi, T 7, \phi 29)$ by ethidium bromide epifluorescent microscopy. Experientia 37, 969-970.

Sugino, A., Peebles, C. L., Kreuzer, K. N. \& Cozzarelli, N. R. (1977). Mechanism of action of nalidixic acid: purification of Escherichia coli nalA gene product and its relationship to DNA gyrase and a novel nicking-closing enzyme. Proceedings of the National Academy of Sciences of the United States of America 74, 4767-4771.

WestmacotT, D. \& Primrose, S. B. (1977). The effect of nalidixic acid on the cell cycle of synchronous Rhodopseudomonas palustris cultures. Journal of General Microbiology 98, 155-166. 